\title{
MODELING THE FATE OF SUMATRAN ELEPHANTS IN BUKIT TIGAPULUH, INDONESIA: RESEARCH NEEDS \& IMPLICATIONS FOR POPULATION MANAGEMENT
}

\author{
ALEXANDER MARKUS MOßBRUCKER ${ }^{1,2^{*}}$, MUHAMMAD ALI IMRON ${ }^{2}$, \\ SATYAWAN PUDYATMOKO ${ }^{2}$, PETER-HINRICH PRATJE ${ }^{3}, \&$ SUMARDI $^{2}$
}

\author{
${ }^{1}$ Sumatran Elephant Conservation Initiative (SECI), Sonnenhalde 7, 78345 Moos, Germany \\ ${ }^{2}$ Faculty of Forestry, Universitas Gadjah Mada, Jl. Agro No. 1 Bulaksumur, Sleman 55281 \\ ${ }^{3}$ Frankfurt Zoological Society (FZS), Jl. A Chatib No. 60, Telanaipura, Jambi 36124 \\ *Email: islandelephants@gmailcom
}

\begin{abstract}
The critically endangered Sumatran elephant persists in mainly small and isolated populations that may require intensive management to be viable in the long term. Population Viability Analysis (PVA) provides the opportunity to evaluate conservation strategies and objectives prior to implementation, which can be very valuable for site managers by supporting their decision making process. This study applies PVA to a local population of Sumatran elephants roaming the Bukit Tigapuluh landscape, Sumatra, with the main goal to explore the impact of pre-selected conservation measures and population scenarios on both population growth rate and extinction probability. Sensitivity testing revealed considerable parameter uncertainties that should be addressed by targeted research projects in order to improve the predictive power of the baseline population model. Given that further habitat destruction can be prevented, containing illegal killings appears to be of highest priority among the tested conservation measures and represents a mandatory pre-condition for activities addressing inbreeding depression such as elephant translocation or the establishment of a conservation corridor.
\end{abstract}

Keywords: Elephas maximus sumatranus, population viability analysis (PVA), Asian elephant, elephant conservation, Vortex.

\section{INTISARI}

Gajah Sumatera yang berstatus kritis sebagian besar bertahan dalam populasi kecil dan terisolasi membutuhkan pengelolaan intensif agar dapat tetap lestari dalam jangka panjang. Analisis Viabilitas Populasi (Population Viability Analysis, PVA) berpeluang untuk digunakan sebagai sarana evaluasi atas tujuan dan strategi konservasi yang disusun sebelum implementasi, yang akan sangat bermanfaat bagi pengelola kawasan guna mendukung pengambilan keputusan. Studi ini menggunakan PVA pada populasi lokal gajah Sumatera yang menjelajahi lanskap Bukit Tigapuluh, Sumatera, dengan tujuan utama mengeksplorasi dampak atas skenario upaya konservasi dan populasi terpilih terhadap laju pertumbuhan populasi dan probabilitas kepunahan. Uji sensitivitas menunjukkan adanya ketidakpastian atas sejumlah parameter pokokyang seharusnya diteliti untuk meningkatkan kekuatan prediksi atas baseline model populasi. Mengingat kerusakan habitat yang lebih parah dapat dicegah, untuk itu upaya penangkalan pembunuhan ilegal merupakan prioritas tertinggi di antara upaya-upaya konservasi yang sudah diuji dan menjadi prasyarat wajib untuk menjawab masalah kemungkinan dampak perkawinan sedarah (inbreeding depression) seperti translokasi gajah atau membangun koridor konservasi.

Kata kunci: Elephas maximus sumatranus, analisis viabilitas populasi (PVA), gajah Asia, konservasi gajah, Vortex. 


\section{INTRODUCTION}

With the exception of rugged and mountainous areas, elephants were once commonly found across the Indonesian island of Sumatra, however during colonial times overexploitation had already reduced their numbers (van Heum 1929 in Santiapillai and Jackson, 1990). Although elephant hunting was banned and the species became protected in Indonesia in 1931, the destruction and fragmentation of elephant habitat continued (Santiapillai and Jackson, 1990), and it was assumed in the 1990s that only 44 relatively small and isolated populations remained in Sumatra (Blouch and Haryanto, 1984; Blouch and Simbolon, 1985). Today, Elephas maximus sumatranus (TEMMINCK 1847) is listed as critically endangered, having lost more than two thirds of its former habitat within just 25 years and suffering from widespread human-elephant conflict and poaching (Gopala et al., 2011).

Genetically and anatomical different from other subspecies (Shoshani and Eisenberg, 1982; Fleischer et al., 2001) Sumatran elephants can be considered an Evolutionary Significant Unit (ESU), with the protection of the remaining wild populations a high priority (Hedges et al., 2005). As conservation resources are scarce and the subspecies' status is critical, there is no room for trial and error approaches in its conservation. Population Viability Analysis (PVA) represents a suitable tool in this context (Brook et al., 2000) that can support various aspects of species management, including assessing vulnerability, impact assessment, and ranking of management options (Akcakaya and Sjögren-Gulve, 2000).

While applications and objectives may vary among studies, PVA always begins with the construction of a population model based on species-specific data that can then be used to model population dynamics under pre-set conditions, with particular focus on the extinction process (see Beissinger and McCullough, 2002, for a thorough overview on methods, concepts, and applications of PVA). Early attempts to model elephant population in a stochastic framework were undertaken in 1980 (Wu and Botkin, 1980) but this mathematically complex model was rarely, if ever, applied to real populations (Sukumar, 2003). About a decade later, others succeeded in modeling elephant populations to evaluate the size of wildlife reserves in Africa (Armbruster and Lande, 1993) and to determine minimum viable population size for Asian elephants (Sukumar, 1993). At about the same time, the first PVA specifically focusing on Sumatran elephants was conducted (Sukumar and Santiapillai, 1993) however, PVA has not subsequently been used to support the conservation and management of individual populations of Sumatran elephants, possibly due to a lack of reliable site-specific information.

We here report the first application of PVA targeting a local population of Sumatran elephants using site-specific baseline information. The primary goal of our study was to explore the effects of a variety of possible population scenarios and management options on the population growth rate of the study population in order to support conservation planning and elephant population management in the region.

\section{MATERIALS \& METHODS}

\section{Study Site and Target Population}

Located roughly in the geographical centre of the Indonesian island of Sumatra $\left(1^{\circ} 4^{\prime} 27.72 " S\right.$, $102^{\circ} 30^{\prime} 43.89^{\prime \prime E}$ ) the Bukit Tigapuluh landscape stretches over more than $3500 \mathrm{~km}^{2}$ of land and two provinces, Riau and Jambi. In addition to extended 
natural forests, the area also includes large commercial agri-and silviculture plantations, areas of coal mining, and subsistence agriculture. While the rugged interior of the landscape is protected by the Bukit Tigapuluh National Park $\left(1,440 \mathrm{~km}^{2}\right)$, most elephants are found in the surroundings towards the south and west of the park (Moßbrucker, 2009; Moßbrucker et al., 2015) that are in large parts dominated by agriculture and silviculture activities (Fig. 1). The landscape is home to the largest known

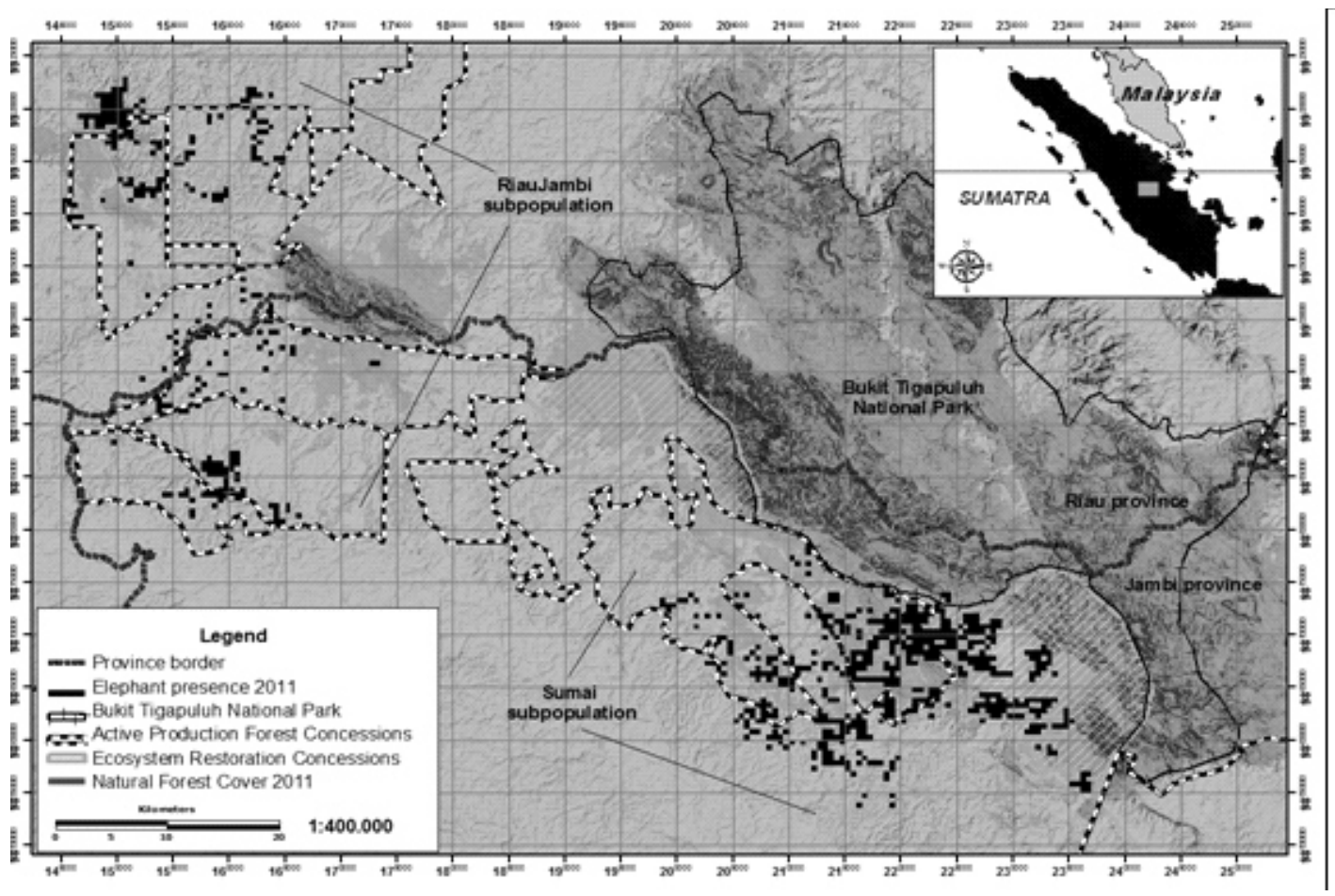

Fig. 1. Overview of elephant distribution and forestry concessions in the Bukit Tigapuluh landscape, Sumatra, Indonesia. (Map data sources: forest cover \& concession information = Frankfurt Zoological Society; administrational borders= BAKOSURTANAL, Bogor 2008; elephant distribution data $=$; hill shade $=$ derived from Shuttle Radar Topography Mission (SRTM) data, courtesy of the U.S. Geological Survey (USGS).

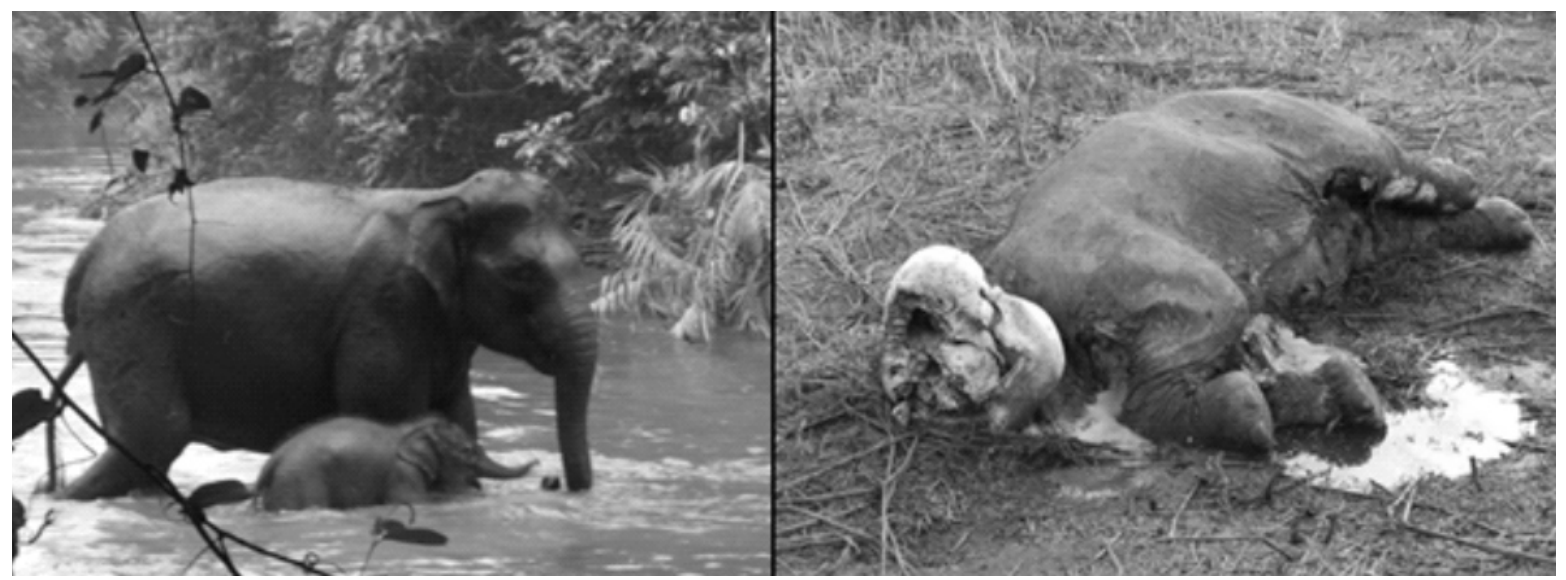

Fig. 2. Sumatran elephants in Bukit Tigapuluh: a cow with calf following her herd into the dense jungle after taking a bath and feeding on water plants (left), and the already decaying remains of a subadult bull that was shot by poachers in order to cut off his small tusks (right). Photo credit: Frankfurt Zoological Society (FZS). 
elephant population of Central Sumatra and thus represents an important area for elephant conservation in Indonesia, however elephant survival in this landscape is jeopardized by ongoing habitat destruction, illegal killings (Fig. 2), and the risk of inbreeding (Moßbrucker et al., 2015).

\section{Baseline Model and Sensitivity Testing}

An individual-based stochastic model of the Bukit Tigapuluh elephant population was constructed using VORTEX 10.1.4.0 (Lacy and Pollak, 2015). Building on the standard settings of the VORTEX model this baseline population model was adjusted based on published species-specific information, site-specific information on the target population, and general biological and ecological considerations as discussed below and summarized in Table 2. A detailed description of the VORTEX population model and its use in PVA is given by Lacy $(1993,2000)$ and Lacy et al. (2015). Sensitivity Testing (ST; see e.g. Imron et al., 2011) was conducted by varying parameter values over their most plausible range. In absence of sound information on the biologically meaningful range for a specific parameter a fixed range of $\pm 20 \%$ of the initial parameter value was used for ST (Table 2). Changes in the stochastic growth rate ( $\mathrm{r}$ ) were used as the main measurement to compare and evaluate ST results, with all outputs compiled using MiCROSOFT EXCEL (2007).

Time frame, stochastic effects, and inbreeding depression

All simulations were set to run over 500 years with 1,000 iterations. This relatively long time frame was chosen to account for the considerable lag phase in the extinction process that was found for long-lived animals such as Asian elephants (Armbruster et al., 1999). Following Sukumar and Santiapillai (1993) stochastic effects were simulated by imposing a standard deviation of $20 \%$ on the mean values of both mortality and reproduction rates. In addition, we allowed for severe catastrophic events ( $50 \%$ reduction of total population size) to occur with a probability of $0.4 \%$ per year geared to the findings of Reed et al. (2003). The negative effects of inbreeding on female fecundity and first-year survival were included by assuming the presence of 6.29 lethal equivalents ( $50 \%$ of the total genetic load due to lethal recessive alleles; O'Grady et al., 2006). An extended possible range of 0-30 lethal equivalents (Lacy et al., 2015) was considered for ST.

\section{Reproductive system and reproductive rates}

The polygynous Asian elephant remains reproductively active into old age but due to a limited age-span in the wild, reproduction may cease at the age of approximately 60 . This age has also been suggested to be the maximum age of wild elephants for demographic purposes (Sukumar, 2003). However, in captivity it has been reported that elephants may occasionally reach 75 years or more (Sukumar and Santiapillai, 1993). Elephants give birth to a single calf after $650-660$ days ( \pm 14 days, roughly 21-22 months) with twins being a rarity (1-2\% of births). While some authors report that elephants generally conceive for the first time at age 10-12 (first offspring born roughly 21-22 months later) there are examples of Asian elephant population that may have their first conception much later, at an age of 15-16 (Sukumar, 2003), and Sukumar (1992) used 17.5 years for the age at first calving for population modeling based on field observations and published research on Asian elephants. Male elephants reach sexual maturity 2-3 years later than females (Sukumar, 2003), and may not successfully sire a calf until they are 20 years or older due to female preferences and competition with 
other males (Sukumar and Santiapillai, 1993; Sukumar, 2003). In addition, only about $80 \%$ of all males may be included into the breeding pool (Sukumar and Santiapillai, 1993). Inter-birth intervals of 4.5-5 years for the Asian elephant have been estimated due to a lactational anestrous of about two years after birth (Sukumar and Santiapillai, 1993), but variations are likely to occur depending on environmental conditions (Sukumar, 2003; Brown, 2006) and for Sumatra, an average of six years has been reported (Santiapillai and Suprahman, 1986, in Sukumar and Santiapillai, 1993). While reliable data is scarce for Sumatran elephants, it can be assumed that Asian elephants living in more stable habitats, such as the tropical rainforests of Indonesia, may in general reach sexual maturity later and have longer inter-calving intervals than those populations that live in more variable habitats, and the low-quality forage available in tropical forest might have a negative influence on general fecundity (Sukumar, 2003). Thus, for the baseline model we choose 18 years for first offspring in females (ST range 12-18 years) and 22 years for first offspring in males (ST range $15-25$ years), and assumed that only $16.67 \%$ of adult females produce offspring each year (inter-calving interval of 6 years; ST range 16.67$22.22 \%$ ). A 50:50 sex ratio at birth was used for the basic model but up to $55 \%$ bias towards males was considered for ST based on field observations of slightly male biased birthrates in captivity (Sukumar and Santiapillai, 1993).

\section{Mortality rates}

Natural mortality rates are difficult to estimate for free-roaming elephants but are generally considered to be relatively low with males suffering from slightly higher mortality than females (Sukumar, 2003). Elephant calves are most vulnerable with a comparatively high mortality of $15 \%$ estimated for the first year after birth. After this time mortality rates decrease substantially, with an estimated 5\% per year for ages $1-5$ and 3\% per year for ages $>5$ years for males, and $4 \%$ per year for ages $1-5$ and $2 \%$ per year for ages $>5$ years for females (Sukumar and Santiapillai, 1993; Armbruster et al., 1999). In addition to natural mortality we included anthropogenic mortality based on monitoring data for Bukit Tigapuluh (Frankfurt Zoological Society, unpublished data 2008-2015). For the baseline model an average of eight females and eight males equally selected from across all age classes were assumed to be killed with a $50 \%$ probability every four years. This accounts for the evidence that elephant killings in Bukit Tigapuluh can equally affect all age classes and both sexes, and may occur bunched in discrete events.

Initial population size, sex ratio, and carrying capacity

Initial population size and sex ratio were both based on the results of a recent survey (Moßbrucker et al., 2015) that found two subpopulations separated by a more than $30 \mathrm{~km}$ wide elephant-free corridor. A total of $99(95 \% \mathrm{CI}=[86,125])$ animals were estimated for Sumai area located just south of the National Park, and $44(95 \% \mathrm{CI}=[37,56])$ animals were estimated for RiauJambi area located in the western part of the landscape. A strongly female biased sex ratio in older age classes was assumed for both subpopulations with the absolute values set based on actual molecular sexing results of the above mentioned survey. A carrying capacity that is slightly higher than the estimated population size (130\% of the initial population size) was used as information gathered during our field observations indicates that healthy animals are not visibly affected by resource limitation, however, the areas they inhabit do not 
appear to allow for a substantial population expansion given the current land use of this area.

\section{Exploration of Management Scenarios}

Using the baseline model as a starting point a variety of different management scenarios were simulated to explore the effect of targeted conservation action on the stochastic growth rate (r) of the population. Changes in $r$ relative to the baseline model $(\Delta \mathrm{r})$ were expressed as a percentage for ease of comparison. In addition, the probability for the population to go extinct over the next 500 years (PE) was estimated, with extinction defined as only one sex remaining. After testing basic management scenarios by changing one parameter at a time we also conducted more complex simulations that involved changes in multiple parameters by combining several of the more simple scenarios. The

Table 1. Description of management scenarios considered to explore the effects of targeted conservation action on the stochastic growth rate and the extinction probability of the Bukit Tigapuluh elephant population.

\begin{tabular}{|c|c|}
\hline Scenario & Description of sub-scenarios \\
\hline $\begin{array}{l}\text { S1: Reduced } \\
\text { anthropogenic } \\
\text { mortality }\end{array}$ & $\begin{array}{l}\text { Effective Human-Elephant Conflict (HEC) mitigation efforts and anti-poaching patrols } \\
\text { decrease the probability that illegal killings (eight elephants killed in each subpopulation } \\
\text { every four years with } 50 \% \text { probability) continue to occur to } 25 \%(\mathrm{~S} 1 \mathrm{a}) \text { or } 5 \%(\mathrm{~S} 1 \mathrm{~b}) \text {. }\end{array}$ \\
\hline $\begin{array}{l}\text { S2: HEC mitigation, } \\
\text { male poaching } \\
\text { continues }\end{array}$ & $\begin{array}{l}\text { Effective HEC mitigation efforts prevent the killing of female elephants and juvenile males } \\
\text { but poaching of subadult and adult bulls for ivory continues to occur with two adult bulls and } \\
\text { one subadult bull killed every four years with } 50 \% \text { (S2a) or } 25 \% \text { probability (S2b). }\end{array}$ \\
\hline $\begin{array}{l}\text { S3: Drastic } \\
\text { carrying ca }\end{array}$ & $\begin{array}{l}\text { The carrying capacity doubles ( } \mathrm{S} 3 \mathrm{a} \text { ) due to substantial habitat improvement and/or } \\
\text { extension, or the carrying capacity is halved ( } \mathrm{S} 3 \mathrm{~b} \text { ) due to a lack of proper habitat protection } \\
\text { causing habitat destruction and/or degradation to continue. }\end{array}$ \\
\hline $\begin{array}{l}\text { S4: Dispersal and } \\
\text { corridors }\end{array}$ & $\begin{array}{l}\text { A corridor is established allowing for occasional male dispersal. Five percent of the young } \\
\text { bulls (age } 12-25 \text { years) disperse each year into the neighboring subpopulation with S4a }= \\
99 \% \text {, and } \mathrm{S} 4 \mathrm{~b}=66 \% \text { probability of survival. In addition, the establishment of a large wildlife } \\
\text { corridor linking both subpopulations and reversing the initial separation completely (S4c) is } \\
\text { tested. }\end{array}$ \\
\hline S5: Transl & $\begin{array}{l}\text { Elephants are occasionally released to mitigate the negative effects of inbreeding } \\
\text { depression. In each subpopulation, one young bull (age } 14-15) \text { is released every } 10 \text { (S5a) or } \\
20 \text { years (S5b), or a small group of four animals ( } 2 \text { adult females age }>17 \text { and } 2 \text { subadults age } \\
10-11) \text { is released every } 40(\mathrm{~S} 5 \mathrm{c}) \text { or } 80 \text { years (S5d). }\end{array}$ \\
\hline $\begin{array}{l}\text { S6: Reduced killings, } \\
\text { translocation, stable } \\
\text { habitat }\end{array}$ & $\begin{array}{l}\text { Continuous habitat protection measures keep the carrying capacity at initial levels. A } \\
\text { corridor is not established but one young bull is released every } 20 \text { years to mitigate } \\
\text { inbreeding depression. Illegal killings can be reduced to occur with a probability of } 25 \% \\
\text { (S6a) or 5\% (S6b), or only poaching of subadult and adult bulls persists with a probability of } \\
50 \% \text { (S6c) or } 25 \% \text { (S6d). }\end{array}$ \\
\hline $\begin{array}{l}\text { S7: Reduced killings, } \\
\text { dispersal, stable } \\
\text { habitat }\end{array}$ & $\begin{array}{l}\text { Continuous habitat protection measures keep the carrying capacity at initial levels. A } \\
\text { corridor is established allowing for occasional male dispersal, with five percent of the young } \\
\text { bulls (age } 12-25 \text { years) dispersing each year into the neighboring subpopulation with a } \\
\text { survival probability of } 66 \% \text {. Illegal killings reduced to occur } 25 \% \text { (S7a) or } 5 \% \text { (S7b) } \\
\text { probability of occurance, or only poaching of subadult and adult bulls persists with a } \\
\text { probability of } 50 \% \text { (S7c) or } 25 \% \text { (S7d). }\end{array}$ \\
\hline
\end{tabular}


choice of scenarios was based on recent discussions with site managers and local authorities as well as recommendations of Moßbrucker et al. (2015) with an explicit focus on those scenarios that were judged to be most realistic and/or suitable for demonstration purposes, rather than including all possible scenarios and combinations in the analysis. Seven main scenarios including several sub-scenarios were considered, resulting into a total of 21 different models (Table 1). In addition to the main analysis for the metapopulation, stochastic growth rates and extinction probabilities were also estimated for both subpopulations separately. All simulations were run over 500 years with 1000 iterations.

\section{RESULTS AND DISCUSSION}

\section{Model Response to Parameter Uncertainties}

The baseline model returned stochastic growth rates of -0.0098 (metapopulation), -0.0089 (Sumai), and -0.0158 (RiauJambi). The probability of extinction over a period of 500 years was estimated at $100 \%$ for RiauJambi and at $91.20 \%$ for both the metapopulation and the Sumai subpopulation. The deterministic growth rate of the baseline model was 0.0064 with a mean generation time of 35.90 years for both sexes combined (Table 3). For ST this baseline model was compared to 40 different simulation scenarios (Table 2) with stochastic growth rate estimates ranging from -0.0165 (30 lethal equivalents) to 0.0005 (22.22\% breeding females per year) and a maximum change in the stochastic growth rate of $\Delta \mathrm{r}=-68.37 \%$ and $\Delta \mathrm{r}=105.10 \%$, respectively (Table 2). Other ST models resulted in larger changes of $r(\Delta r> \pm 25 \%)$ included the maximum lifespan and maximum age of reproduction $(\Delta \mathrm{r}=60.20 \%)$, the percentage of males at birth $(\Delta r=-33.67 \%)$, age of first reproduction of females $(\Delta r=59.18 \%)$, the mortality rate for females older than 5 years $(\Delta \mathrm{r}=-40.82 \%$ to $47.96 \%)$, and anthropogenic mortality ( $\Delta \mathrm{r}=-28.57 \%$ to $25.51 \%)$.

The variation of parameter values within the set boundaries for ST revealed the considerable impact that present parameter uncertainties can have on the population model. Accordingly, the predictive power of the model is limited and care must be taken not to overstate absolute modeling results, with the true value of the model lying in comparison of relative differences among the various test- and management scenarios rather than in accurately predicting future population developments. Furthermore, the ST results underline the need for sound research that should focus on those parameters for which parameter uncertainties have resulted in an extremely broad range of stochastic growth rate estimates. Among these, parameters defining fertility and mortality of female elephants had especially strong effects on the model, with the largest growth rate increase caused by decreasing the inter-calving interval to 4.5 years.

Inter-calving intervals appear to be quite variable not only for Asian elephants but also for their relatives in Africa, where mean intervals from 3.3 years (Gough and Kerley, 2006; Foley and Faust, 2010) to 9.1 years (Laws et al., 1975, in Wittemyer et al., 2013) have been estimated. Growing evidence supports the hypothesis that mean inter-calving intervals and population dynamics in general are also influenced by human impacts, with populations exposed to increased anthropogenic mortality showing greater reproduction effort than those living under stable conditions (Wittemyer et al., 2013). If similar responses occur for Sumatran elephants, the actual growth rate could be larger than that estimated by our conservative baseline model, raising hopes that the Bukit Tigapuluh population could cope 
better with current poaching pressure, and recover faster than predicted if given the opportunity.

A strong impact on the baseline model was also encountered for the tested range of lethal equivalents. While information on the actual genetic load and inbreeding level is absent for Bukit Tigapuluh, considerable disturbances of population growth caused by inbreeding and bottleneck effects must be taken into account considering the small size and skewed sex ratio of the population. The ST results for the possible range of lethal equivalents clearly demonstrate both the considerable potential negative impact of inbreeding and the potential positive impact genetic supplementation could have on the

Table 2. Parameter Values (PV) used for constructing the baseline model of the Bukit Tigapuluh elephant population, the PV value range variation used for Sensitivity Testing (ST range), and the for each ST scenario estimated stochastic growth rate range $(\mathrm{r}(\mathrm{ST})$ ) including the change in $\mathrm{r}(\mathrm{ST})$ relative to the baseline model $(\Delta \mathrm{r})$.

\begin{tabular}{l} 
Parameter Description \\
\hline Lethal equivalents \\
Percent due to lethal alleles [\%] \\
Maximum lifespan \& maximum age of \\
reproduction [y]
\end{tabular}

Percentage of males at birth [\%]

Litter size

Age at first reproduction, males [y]

Age at first reproduction, females [y]

Breeding females each year [\%]

Males in breeding pool

Mortality rate males [\%]

Mortality rate females [\%]

$$
\begin{gathered}
\text { age } 0-1 \text { year } \\
\text { age } 1-5 \text { years } \\
\text { age }>5 \text { years }
\end{gathered}
$$

$$
\begin{gathered}
\text { age } 0-1 \text { year } \\
\text { age } 1-5 \text { years } \\
\text { age }>5 \text { years }
\end{gathered}
$$

\begin{tabular}{|c|c|c|c|}
\hline PV & ST range & $r(S T)$ & $\Delta \mathrm{r}[\%]$ \\
\hline 6.29 & $0 \mid 30$ & $-0.0038 \mid-0.0165$ & $61.22 \mid-68.37$ \\
\hline 50 & $+/-20 \%$ of $\mathrm{PV}$ & $-0.0096 \mid-0.0101$ & $2.04 \mid-3.06$ \\
\hline 60 & $60 \mid 75$ & $-0.0098 \mid-0.0039$ & $0.00 \mid 60.20$ \\
\hline 50 & $50 \mid 55$ & $-0.0098 \mid-0.0131$ & $0.00 \mid-33.67$ \\
\hline 1 & - & - & \\
\hline 22 & $15 \mid 25$ & $-0.0098 \mid-0.0095$ & $0.00 \mid 3.06$ \\
\hline 18 & $12 \mid 18$ & $-0.0040 \mid-0.0098$ & $59.18 \mid 0.00$ \\
\hline 16.67 & $16.67 \mid 22.22$ & $-0.0098 \mid 0.0005$ & $0.00 \mid 105.10$ \\
\hline 80 & $+/-20 \%$ of PV & $-0.0097 \mid-0.0101$ & $1.02 \mid-3.06$ \\
\hline 15 & $+/-20 \%$ of PV & $-0.0095 \mid-0.0101$ & $3.06 \mid-3.06$ \\
\hline 5 & $+/-20 \%$ of PV & $-0.0099 \mid-0.0099$ & $-1.02 \mid-1.02$ \\
\hline 3 & $+/-20 \%$ of $\mathrm{PV}$ & $-0.0104 \mid-0.0096$ & $-6.12 \mid 2.04$ \\
\hline 15 & $+/-20 \%$ of PV & $-0.0111 \mid-0.0087$ & $-13.27 \mid 11.22$ \\
\hline 4 & $+/-20 \%$ of PV & $-0.0109 \mid-0.0087$ & $-11.22 \mid 11.22$ \\
\hline 2 & $+/-20 \%$ of PV & $-0.0138 \mid-0.0051$ & $-40.82 \mid 47.96$ \\
\hline
\end{tabular}

Catastrophic events [\%]

$$
\begin{gathered}
\text { decrease of population size } \\
\text { probability of occurrence }
\end{gathered}
$$

Anthropogenic mortality

Initial population size

\begin{tabular}{rrrrrr} 
& Sumai & 99 & $86 \mid 125$ & $-0.0110 \mid-0.0078$ & $-12.24 \mid 20.41$ \\
Carrying Capacity & 44 & $37 \mid 56$ & $-0.0100 \mid-0.0098$ & $-2.04 \mid 0.00$ \\
& & $130 \%$ of initial & $+/-20 \%$ of PV & $-0.0086 \mid-0.0116$ & $12.24 \mid-18.37$ \\
& & & & \\
\hline
\end{tabular}

$+/-20 \%$ of PV $\quad-0.0104 \mid-0.0092$

$-6.12 \mid 6.12$

0.40 per year

$+/-20 \%$ of PV

$-0.0106 \mid-0.0092$

$-8.16 \mid 6.12$

16 deaths in 4

$+/-20 \%$ of

$-0.0126 \mid-0.0073$

$-28.57 \mid 25.51$ years with $50 \%$

probability

probability 
study population. Genetic monitoring and management should thus be considered to become part of management toolkit for Bukit Tigapuluh.

Another parameter that can be directly influenced by management action is anthropogenic mortality. Even the slight changes of mortality probabilities applied for ST had considerable effects on the growth rate, indicating the significance of elephant protection measures as a primary conservation objective. The sensitive response of the model towards a slight male bias at birth was somewhat surprising, however further underlines the important role of females as drivers of elephant population dynamics. While it is not possible to prove any deviation from equal intrinsic sex ratios at birth based on currently available datasets, we hope that an increase in thorough population studies will shed more light on this issue in the future.

\section{Exploration of Management Scenarios}

The exploration of management scenarios resulted into stochastic growth rate estimates ranging from $-0.0195(\mathrm{~S} 4 \mathrm{~b}, \Delta \mathrm{r}=\mathrm{-98} .98)$ to 0.0017 (S6b, $\Delta \mathrm{r}$ $=117.35 \%)$ for the metapopulation, and from

Table 3. Probability of extinction (PE), stochastic growth rate (r), and change in $r$ relative to the baseline model $(\Delta \mathrm{r})$ for 21 management scenarios and the baseline population model $(\mathrm{BM})$ of the Bukit Tigapuluh elephant population. Modeling results for the metapopulation and both subpopulation are shown separately.

\begin{tabular}{|c|c|c|c|c|c|c|c|c|c|}
\hline \multirow[b]{2}{*}{ Scenario } & \multirow[b]{2}{*}{ PE [\%] } & \multicolumn{2}{|c|}{ Metapopulation } & \multicolumn{4}{|c|}{$\begin{array}{l}\text { Subpopulation } \\
\text { "Sumai" }\end{array}$} & \multicolumn{2}{|c|}{$\begin{array}{l}\text { Subpopulation } \\
\text { "RiauJambi" }\end{array}$} \\
\hline & & $\mathbf{r}$ & $\Delta \mathrm{r}[\%]$ & PE [\%] & $\mathbf{r}$ & $\Delta \mathbf{r}[\%]$ & PE [\%] & $\mathbf{r}$ & $\Delta \mathrm{r}[\%]$ \\
\hline $\mathrm{S} 4 \mathrm{~b}$ & 100.00 & -0.0195 & -98.98 & 100.00 & -0.0182 & -104.49 & 100.00 & -0.0119 & 24.68 \\
\hline $\mathrm{S} 3 \mathrm{~b}$ & 100.00 & -0.0154 & -57.14 & 100.00 & -0.0135 & -51.69 & 100.00 & -0.0237 & -50.00 \\
\hline S4a & 100.00 & -0.0123 & -25.51 & 100.00 & -0.0120 & -34.83 & 100.00 & -0.0050 & 68.35 \\
\hline $\mathrm{S} 4 \mathrm{c}$ & 94.60 & -0.0110 & -12.24 & 94.60 & -0.0110 & -23.60 & 94.60 & -0.0110 & 30.38 \\
\hline BM & 91.20 & -0.0098 & 0.00 & 91.20 & -0.0089 & 0.00 & 100.00 & -0.0158 & 0.00 \\
\hline $\mathrm{S} 5 \mathrm{~b}$ & 82.40 & -0.0084 & 14.29 & 82.60 & -0.0076 & 14.61 & 100.00 & -0.0127 & 19.62 \\
\hline S5a & 78.10 & -0.0067 & 31.63 & 78.20 & -0.0065 & 26.97 & 99.90 & -0.0106 & 32.91 \\
\hline S3a & 63.70 & -0.0066 & 32.65 & 63.70 & -0.0058 & 34.83 & 100.00 & -0.0145 & 8.23 \\
\hline S5d & 67.60 & -0.0063 & 35.71 & 67.80 & -0.0055 & 38.20 & 99.90 & -0.0120 & 24.05 \\
\hline $\mathrm{S} 5 \mathrm{c}$ & 43.70 & -0.0037 & 62.24 & 46.50 & -0.0033 & 62.92 & 93.90 & -0.0075 & 52.53 \\
\hline S1a & 43.20 & -0.0036 & 63.27 & 44.80 & -0.0028 & 68.54 & 97.50 & -0.0078 & 50.63 \\
\hline S7a & 39.40 & -0.0032 & 67.35 & 43.90 & -0.0028 & 68.54 & 78.70 & -0.0032 & 79.75 \\
\hline S6a & 20.70 & -0.0017 & 82.65 & 28.50 & -0.0013 & 85.39 & 79.80 & -0.0048 & 69.62 \\
\hline $\mathrm{S} 2 \mathrm{a}$ & 28.10 & -0.0011 & 88.78 & 29.20 & -0.0003 & 96.63 & 95.10 & -0.0060 & 62.03 \\
\hline $\mathrm{S} 1 \mathrm{~b}$ & 16.20 & -0.0005 & 94.90 & 20.00 & 0.0001 & 101.12 & 80.60 & -0.0041 & 74.05 \\
\hline $\mathrm{S} 2 \mathrm{~b}$ & 15.00 & -0.0003 & 96.94 & 17.70 & 0.0003 & 103.37 & 86.60 & -0.0047 & 70.25 \\
\hline S7c & 24.60 & -0.0001 & 98.98 & 28.70 & -0.0001 & 98.88 & 43.20 & -0.0002 & 98.73 \\
\hline S7d & 12.30 & 0.0007 & 107.14 & 15.50 & 0.0004 & 104.49 & 30.90 & 0.0007 & 104.43 \\
\hline S6c & 7.70 & 0.0010 & 110.20 & 12.20 & 0.0013 & 114.61 & 62.30 & -0.0025 & 84.18 \\
\hline S7b & 4.50 & 0.0016 & 116.33 & 9.20 & 0.0011 & 112.36 & 21.90 & 0.0017 & 110.76 \\
\hline S6d & 2.60 & 0.0016 & 116.33 & 6.30 & 0.0016 & 117.98 & 36.70 & -0.0008 & 94.94 \\
\hline S6b & 2.00 & 0.0017 & 117.35 & 6.80 & 0.0017 & 119.10 & 39.20 & -0.0008 & 94.94 \\
\hline
\end{tabular}


$-0.0182(\mathrm{~S} 4 \mathrm{~b}, \Delta \mathrm{r}=-104.49 \%)$ to 0.0017 (S6b, $\Delta \mathrm{r}=$ $-119.10 \%)$ and -0.0237 (S3b, $\Delta \mathrm{r}=-50.00 \%$ ) to 0.0017 (S7b, $\Delta \mathrm{r}=110.76 \%$ ) for the subpopulations Sumai and RiauJambi, respectively (Table 3). Extinction probabilities ranged from 100\% (S3b, $\mathrm{S} 4 \mathrm{a}, \mathrm{S} 4 \mathrm{~b}$ ) to $2.00 \%$ (S6b) for the metapopulation and from $100 \%(\mathrm{~S} 3 \mathrm{~b}, \mathrm{~S} 4 \mathrm{a}, \mathrm{S} 4 \mathrm{~b})$ to $6.30 \%$ (S6d) and $100 \%$ (S3a, S3b, S4a, S4b, S5b) to $21.90 \%$ (S7b) for Sumai and Riau Jambi, respectively.

Among the tested single parameter-change management scenarios (S1-S5) those simulations that decreased the probability of illegal killings to occur (S1 and S2) had the strongest positive impact on the metapopulation, demonstrating the great potential of elephant protection measures for the conservation of the Bukit Tigapuluh elephants. Efforts to decrease the probability of elephants being killed by poachers or being caught up in Human-Elephant Conflict (HEC) must thus be of high priority for site managers. It has been successfully demonstrated that targeted conservation activities can in fact reduce illegal killing to very low levels in the Sumai subpopulation, with only two elephants killed over a period of more than six years (FZS unpublished reports year 2010-2016). However, it must be noted that long-term success would likely need to include additional conservation measures, as discussed in subsequent paragraphs.

Not surprisingly, a drastic decrease in carrying capacity (S3b) did substantially decrease both growth rate and survival chances, clearly demonstrating the need to prevent further habitat destruction and degradation. Interestingly, doubling the carrying capacity (S3a) would only lead to a comparatively modest increase in growth rates. However, although the carrying capacity is linked to the animal's habitat, care has to be taken not to hastily dampen frequent calls for habitat restoration within the elephant range based on these findings. Recent research and monitoring results indicate that all known elephant home ranges in the study area include less than $50 \%$ of natural forest (Moßbrucker et al. to be submitted) and that HEC is with 119 to 186 cases per year very common (Frankfurt Zoological Society, unpublished reports 2011-2015). While HEC mitigation is certainly contributing positively to elephant conservation, it is unlikely that HEC can be permanently reduced to levels for which the risk of killings becomes negligible if the elephants are not able to satisfy their basic needs away from fields and villages. Therefore, the role of the habitat must not be underestimated as there is certainly more to it than merely determining baseline carrying capacity. Subject to the degree of which elephants are depending on raiding field crops, habitat restoration may be absolutely critical to bolstering the management objectives described in S1 and S2 over the long term. A legal option for habitat restoration in the Bukit Tigapuluh landscape is provided via ecosystem restoration concessions (Menteri Kehutanan, 2004) and elephant friendly management of existing production forest concessions.

Translocation of elephants (S5) is technically feasible but would be a complex venture that would require intensive preparation, involve various risks and high costs, and would be logistically very demanding (Dublin and Niskanen, 2003). In addition, due to the elephant's social structure and behavior (see, inter alia, Sukumar, 2003; de Silva and Wittemyer, 2012) target animals for translocation would need to be carefully selected. Bulls may be best translocated after becoming fully independent from their family group but before they settled into a fixed home range that they may attempt to return to after translocation, and females should 
only be translocated in units of established family groups. The translocation of problem elephants may cause more problems than it solves (Fernando et al., 2012) and should thus not be considered to become a routine intervention. In spite of these concerns and challenges, translocation may be necessary some degree to prevent inbreeding depression, and our simulations demonstrate the potential translocation can have for elephant conservation in Bukit Tigapuluh. Not surprisingly, the translocation of small female groups (S5c, S5d) has shown to be roughly twice as effective as the translocation of the same number of bulls (S5a, S5b) over a certain period of time, because under the given population scenario translocations will not only genetically enrich the population but, in case of females being translocated, also substantially increase the number of possible births per year and thus increase breeding capacity. As the modeled population is suffering from anthropogenic mortality, translocation would also to some extend merely counterbalance losses. In such a situation translocation would not be a recommended management action (Dublin and Niskanen, 2003), but would need to be combined with elephant protection measures, as simulated in scenario S6. With anthropogenic mortality contained, even positive growth rates can be reached for the metapopulation, reducing the extinction probability to very low levels $(6 \mathrm{~b}, 6 \mathrm{c}, 6 \mathrm{~d})$.

Establishing a conservation corridor between both subpopulations (S4) appears to be the most straightforward approach to address the risk of inbreeding, as it would increase the total effective breeding population size of the metapopulation. However, the usefulness of corridors for species conservation is controversial (see, inter alia, Simberloff and Cox, 1987; Noss, 1987; Simberloff et al., 1992; and Rosenberg et al., 1997) and it appears that a general consensus is neither possible nor desirable, but instead, each specific case needs to be evaluated thoroughly in order to decide if and how corridors may be of benefit under given circumstances and conditions (Bennet, 2003). Our simulations represent a good example for how differently a corridor can impact a population, depending on additional co-factors. Given that anthropogenic mortality is not contained a corridor would negatively affect the Bukit Tigapuluh metapopulation, even if the passage would be comparatively safe (S4b) and both subpopulations would be completely re-united (S4c). This seems odd at first but is explained by the fact that while both subpopulations are exposed to identical killing rates, they are of different size, causing a higher effective per capita risk for illegal killings in RiauJambi area than in Sumai area. Increasing the permeability for animals in between the two areas, or joining both sub-populations, would thus increase the overall risk of getting killed for animals from the comparatively safer Sumai sub-population, outweighing both the benefit for the RiauJambi subpopulation and the general decrease of the inbreeding risk. This pictures changes dramatically however if the dispersal corridor is accompanied by elephant protection efforts in the core habitat. Growth rates increase steeply given a low probability for anthropogenic mortality, reaching even positive values for both subpopulations and the metapopulation, accompanied by relatively low extinction probabilities (S7b, S7d). A corridor could therefore represent a valuable conservation strategy but must be combined with effective elephant protection measures in order to prevent potential negative impacts on the survival of the metapopulation. 


\section{CONCLUSIONS}

While absolute results need to be interpreted cautiously due to considerable parameter uncertainties (up to $\Delta \mathrm{r}=-68.37 \%$ and $\Delta \mathrm{r}=105.10 \%$ ) that require further research in order to increase the predictive power and reliability of the baseline model, it must be assumed that the Bukit Tigapuluh elephant population will require intense management in order to survive in the long term. The estimated probability of extinction over a period of 500 years for the metapopulation is with $91 \%$ extremely high, and keeping status quo thus not desirable. While certainly multiple conservation measures need to be implemented to avoid the local extinction of the Sumatran elephant in Bukit Tigapuluh, priority should be given to activities that prevent further habitat destruction and reduce the occurrence of illegal killings. Based on our simulations, a substantial decrease of the risk of elephants getting killed (S1b) would increase the growth rate by $95 \%$ and the extinction probability would decrease to only $16 \%$. While anti-poaching efforts are the most important activity in this context, effective elephant protection may also require partial habitat restoration as one of the primary reasons for illegal killings, human-elephant conflict, can only be successfully addressed if elephants are able to satisfy their basic needs away from fields and human habitation. Activities addressing inbreeding depression such as elephant translocation or the establishment of a conservation corridor are important to bolster the long-term survival of the population but should only be considered after both habitat and elephant protection measures become effective at the landscape level, as otherwise drastic negative effects must be expected (e.g. S4: $\mathrm{PE}=95-100 \%, \Delta \mathrm{r}=$ $-12.24 \%$ to $-98.98 \%$ ). Given that anthropogenic mortality can be contained, a conservation corridor
(S7b) and occasional elephant translocation (S6b) could increase the growth rate of the metapopulation to $116 \%$ and $117 \%$ and decrease the probability of extinction to up to $5 \%$ and $2 \%$, respectively.

\section{ACKNOWLEDGEMENTS}

We thank the U.S. Fish \& Wildlife Service (USFWS), the International Elephant Project (IEP), and Perth Zoo (Western Australia) for financial support, and the Indonesian State Ministry of Research and Technology (RISTEK) for granting research permits. We are grateful to the Department of Conservation of Natural Resources and Ecosystem (Konservasi Sumber Daya Alam dan Ekosistem, KSDAE) for their eager support of elephant conservation and research in the region. Further, the authors thank Dr. Amanda Fernie for carefully reviewing the English, Widyaningsih Peni Lestari for translating the abstract, and Veterinarian Christopher Stremme for interesting discussions on elephant biology.

\section{REFERENCES}

Akcakaya HR \& Sjögren-Gulve P. 2000. Population viability analyses in conservation planning?: an overview. Ecological Bulletins 48, 9-21.

Armbruster P, Fernando P, \& Lande R. 1999. Time frames for population viability analysis of species with long generations: an example with Asian elephants. Animal Conservation 2, 69-73.

Armbruster P \& Lande R. 1993. A population viability analysis for African Elephant (Loxodonta africana): How big should reserves be? Conservation Biology 7, 602-610.

Beissinger SR \& McCullough DR (Eds). 2002. Population Viability Analysis. First edition. University of Chicago Press, Chicago. 593.

Bennett AF. 2003. Linkages in the Landscape: The Role of Corridors and Connectivity in Wildlife Conservation. IUCN Publications Services Unit, UK, Gland, Switzerland, and Cambrige, UK. 255. 
Blouch RA \& Haryanto. 1984. Elephants in Southern Sumatra. Unpublished Report. IUCN/WWF Project 3033. Bogor.

Blouch RA \& Simbolon K. 1985. Elephants in Northern Sumatra. Unpubplished Report. IUCN/WWF Project 3033. Bogor.

Brook BW, O'Grady JJ, Chapman AP, Burgman MA, Akçakaya HR, \& Frankham R. 2000. Predictive accuracy of population viability analysis in conservation biology. Nature 404, 385-387.

Brown JL. 2006. Reproductive endocrinology. In: Biology, Medicine, and Surgery of Elephants. First edition. Fowler ME \& Mikota SK (Eds). Blackwell Publishing, Oxford. 377-389.

Dublin HT \& Niskanen LS. Eds. 2003. The African Elephant Specialist Group in Cooperation with the Re-introduction and Veterinary Specialist Groups 2003. IUCN/SSC AfESG Guidelines for the in situ Translocation of the African Elephant for Conservaiton Purposes. First edition. IUCN, Gland, Switzerland, and Cambridge, UK. 55.

Fernando P, Leimgruber P, Prasad T, \& Pastorini J. 2012. Problem-elephant translocation: translocating the problem and the elephant? PloS one 7.

Fleischer RC, Perry EA, Muralidharan K, Stevens EE, \& Wemmer CM. 2001. Phylogeography of the Asian elephant (Elephas maximus) based on Mitochondrial DNA. Evolution 55, 1882-1892.

Foley CAH \& Faust LJ. 2010. Rapid population growth in an elephant Loxodonta africana population recovering from poaching in Tarangire National Park, Tanzania. Oryx 44, 205.

Gopala A, Hadian O, Sunarto, Sitompul A, Williams A, Leimgruber P, Chambliss SE, \& Gunaryadi D. 2011. Elephas maximus ssp. Sumatranus. The IUCN Red List of Threatened Species 2011: e.T199856A9129626

http://dx.doi.org/10.2305/IUCN.UK.2011-2.RL TS.T199856A9129626.en

Gough KF \& Kerley GIH. 2006. Demography and population dynamics in the elephants Loxodonta africana of Addo Elephant National Park, South Africa: is there evidence of density dependent regulation? Oryx 40, 434-441.

Hedges S, Tyson MJ, Sitompul AF, Kinnaird MF, \& Gunaryadi D. 2005. Distribution, status, and conservation needs of Asian elephants (Elephas maximus) in Lampung Province, Sumatra, Indonesia. Biological Conservation 124, 35-48. van Heum FC. 1929. Die Olifanten van Sumatra. Druk. Gerretsen, Den Haag.

Imron MA, Gergs A, \& Berger U. 2011. Structure and sensitivity analysis of individual-based predator-prey models. Reliability Engineering \& System Safety 107, 71-81.

Lacy RC. 1993. VORTEX: a computer simulation model for population viability analysis. Wildlife Research 20, 45-65.

Lacy RC. 2000. Structure of the VORTEX simulation model for population viability analysis. Ecological Bulletins 48, 191-203.

Lacy RC, Miller PS, \& Traylor-Holzer K. 2015. Vortex 10 User's Manual. 15 April 2015 update. Apple Valley, Minnesota, USA.

Lacy RC \& Pollak JP. 2015. Vortex : A Stochastic Simulation of the Extinction Process. Version 10.1. Brookfield, Illinois, USA.

Laws RM, Parker ICS, \& Johnstone RCB. 1975. Elephants and Their Habitats: The Ecology of Elephants in North Bunyoro, Uganda. Clarendon Press, Oxford, U.K. 388.

Menteri Kehutanan. 2004. Peraturan Menteri Kehutanan Nomor?: SK.159/Menhut-II /2004 Restorasi Ekosistem di Kawasan Hutan Produksi. Indonesia.

Moßbrucker AM. 2009. Zum Status des Sumatra Elefanten (Elephas maximus sumatranus) im Landschaftsraum Bukit Tigapuluh, Sumatra, Indonesien?: Abundanz Altersstruktur und Gefährdung. Diplomarbeit (unpublished).Universtiy of Freiburg, Freiburg, Germany.

Moßbrucker AM, Apriyana I, Fickel J, Imron MA, Pudyatmoko S, Sumardi, \& Suryadi H. 2015. Non-invasive genotyping of Sumatran elephants?: implications for conservation. Tropical Conservation Science 8,745-759.

Moßbrucker AM, Fleming $\mathrm{CH}$, Imron MA, Pudyatmoko S, \& Sumardi. (n.d.). AKDE home range size and habitat selection of Sumatran elephants in Bukit Tigapuluh. Submitted to Wildlife Research.

Noss RF. 1987. Corridors in real landscapes: A reply to Simberloff and Cox. Conservation Biology 1, 59-164.

O'Grady JJ, Brook BW, Reed DH, Ballou JD, Tonkyn DW, \& Frankham R. 2006. Realistic levels of inbreeding depression strongly affect extinction risk in wild populations. Biological Conservation 133, 42-51. 
Reed DH, O'Grady JJ, Ballou JD, \& Frankham R. 2003. The frequency and severity of catastrophic die-offs in vertebrates. Animal Conservation 6,109-114.

Rosenberg DK, Noon BR, \& Meslow EC. 1997. Biological corridors: Form, function, and efficacy. BioScience 47, 677-687.

Santiapillai C \& Jackson P. 1990. The Asian Elephant. An Action Plan for its Conservation. Gland, Switzerland. 79.

Santiapillai C \& Suprahman H. 1986. The ecology of the elephant (Elephas maximus L.) in the Way Kambas Game Reserve, Sumatra. WWF/IUCN Project 3133 Report. Bogor, Indonesia.

Schmitt D. 2006. Reproductive System. In: Biology, Medicine, and Surgery of Elephants. Fowler ME \& Mikota SK (Eds). First edition. Blackwell Publishing, Oxford. 347-357.

Shoshani J \& Eisenberg JF. 1982. Elephas maximus. Mammalian Species 182, 1-8.

de Silva SD \& Wittemyer G. 2012. A comparison of social organization in Asian elephants and African savannah elephants. International Journal of Primatogology 33, 1125-1141.

Simberloff D \& Cox J. 1987. Consequences and costs of conservation corridors. Conservation Biology 1, 63-71.

Simberloff D, Farr JA, Cox J, \& Mehlman DW. 1992. Movement corridors: Conservation bargains or poor investments? Conservation Biology 6, 493-504.

Sukumar R. 1992. The Asian Elephant: Ecology and Management. Cambridge Studies in Applied Ecology and Resource Management. 255.

Sukumar R. 1993. Minimum viable populations for elephant conservation. Gajah 11, 48-52.

Sukumar R. 2003. The Living Elephants: Evolutionary Ecology, Behavior, and Conservation. Oxford University Press, Oxford. 478.

Sukumar R \& Santiapillai C. 1993. Asian elephant in Sumatra Population and habitat viability analysis. Gajah 11, 59-63.

Wittemyer G, Daballen D, \& Douglas-hamilton I. 2013. Comparative demography of an at-risk African elephant population. PloS one 8, 1-10.

Wu LS \& Botkin DB. 1980. Of elephants and men: A discrete, stochastic model for long-lived species with complex life histories. The American Naturalist 116, 831-849. 